\title{
INFLUENCE OF TIME DELAYS OF ROBOTIC TOTAL STATIONS WITCH HIGH SAMPLING FREQUENCY ON ACCURACY OF MEASUREMENTS TO MOVING PRISMS
}

\author{
G. LENDA ${ }^{1}$, A. UZNAŃSKI ${ }^{2}$, M. STRACH ${ }^{3}$
}

\begin{abstract}
Robotic total stations are a group of surveying instruments that can be used to measure moving prisms. These devices can generate significant errors during kinematic surveys. This is due to the different speeds of the total station's measurement subsystems, which results in the observations of the point location being performed in different places of the space. Total stations which are several years old may generate errors of up to a few dozen centimeters. More modern designs, with much lower delays of the mechanical and electronic subsystems, theoretically allow to significantly reduce the values of the errors. This study involved the performance of kinematic tests on the modern robotic total station Leica MS50 in order to determine the values of measurement errors, and also to define the possibility of using them for the above-mentioned applications.
\end{abstract}

Keywords: measurement to a mobile target, position measurement, kinematic measurement, measurement techniques, robotic total stations

\section{INTRODUCTION}

A great number of decisions associated with the assessment of technical condition of engineering structures are made based on precise geodetic measurements. A great number of decisions associated with the assessment of technical condition of engineering structures are made based on precise geodetic measurements.

${ }^{1}$ PhD., Eng., AGH University of Science and Technology, Faculty of Mining Surveying and Environmental Engineering, Al. Mickiewicza 30,30-059 Krakow, Poland, e-mail: grzenda@agh.edu.pl

${ }^{2} \mathrm{PhD}$., Eng., AGH University of Science and Technology, Faculty of Mining Surveying and Environmental Engineering, Al. Mickiewicza 30, 30-059 Krakow, Poland, e-mail: auznan@agh.edu.pl

${ }^{3}$ DSc., PhD., Eng., AGH University of Science and Technology, Faculty of Mining Surveying and Environmental Engineering, Al. Mickiewicza 30, 30-059 Krakow, Poland, e-mail: strach@agh.edu.pl 
Currently, tacheometric measurement techniques, GNSS satellite surveys as well as terrestrial and mobile laser scanning are the most commonly used ones. The results of these measurements may be encumbered with significant errors even when using very advanced electronic surveying instruments. The manufacturer's technical specification is the standard basis for assessing the applicability of a given measurement instrument. The accuracy specified therein usually refers to measurements of static targets. However, for some types of instruments, actual parameters may deviate significantly from the specification if measurements are performed in the kinematic mode. The reason may lie in insufficient internal synchronization of various component sub-systems of the instrument. Robotic total stations, which have been available on the market for some time now, allow to record the position of a moving prism. They may be used in works with different accuracy requirements, usually ranging from single millimeters for engineering structures and technical infrastructure, to several dozen millimeters for natural or earth structures. Higher accuracy measurements can be performed e.g. to adjust the axis of railway tracks - the task which is carried out periodically to restore the desired geometry of the tracks, thus conditioning the safe and smooth operation of trains at the predetermined speed. They may also be used for overhead cranes of considerable lengths located in industrial plants and, additionally, to control machine systems. Lower accuracy is required e.g. to determine the position of the echosounder examining the shape of the bottom of water reservoirs, or to determine the position of the ground-penetrating radar defining the depth and shape of underground objects. They can also be used to create a digital terrain model. In general, they can be used to measure all elongated objects for which, due to the need to capture a dense set of observations and their considerable size, it is economical to make observations using a prism moving around this object. However, measurements of mobile targets, which are to ensure a certain accuracy in determining the geometry of objects conditioning their functionality or safety, are subject to the occurrence of significant measurement errors related to time delays in data recording in total station measuring systems. In some unfavorable cases, these errors can reach the value of up to a few dozen centimeters. So far, relatively few studies have been devoted to this topic, and continuous progress in the field of mechanics, electronics and software solutions makes new total stations much less vulnerable to the occurrence of such measurement errors.

The position of a moving prism is determined in the same way as the position of stationary targets, i.e. by measuring the distance, vertical angle and horizontal angle. For technical reasons, these three quantities can not be recorded at exactly the same time. This does not matter for static measurements, because the point remains at rest. During robotic measurements, however, when the 
prism is continuously moving, mutual time delays in recording distances and angles may negatively affect the accuracy because the point location consists of observations made in various places in space. The consequences of delays are illustrated in Figure 1a. The prism moves along the straight line to the right and is observed from the station S. Since measurements of distances take longer than measurements of angles, if all observations are commenced at the same moment, a delay in recording distances relative to angles will be triggered. The distances $d_{i}$ will be linked to the angles $\alpha_{i}$ recorded in the previous position of the prism. As a result, the determined trajectory will be shifted away from the rectilinear motion path. This shift will continue to increase until the prism achieve position of the measuring station, then it will rapidly change the sign to the opposite one, and next decrease as it moves away from this station.
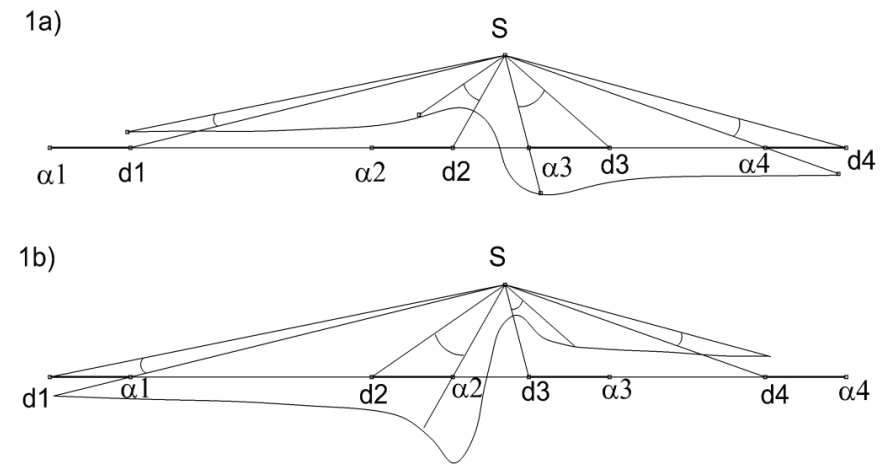

Fig. 1. Influence of time delays on accuracy of determining position of a mobile prism moving along a straight line. 1a - delays in recording distances in relation to angles, $1 \mathrm{~b}$ - delays in recording angles in relation to distances. The bold line represents distance traveled by prism between recording time of distances and angles, $\mathrm{S}$ - station.

In order to limit the influence of delays, usually considerable ones, in recording distances relative to angles, the angles should be recorded after the distances have already been measured. This will significantly reduce the scale of the phenomenon, and the deviation graph will be reversed, because this time the angles will be delayed in relation to the distances (Fig. 1b). In practice, the record of vertical and horizontal angles does not occur at the same moment either, which is conditioned by the various instrumental adjustments introduced. During the performance of the measurement, the actions of the four types of sensors affect the measurement time: angle encoders, ATR - automatic target recognition system, total station main axis tilt compensator and EDM - electro-optical 
distance measuring system [14]. The angular values calculated by the instrument take into account the quantities contained in formulas - Eq. (1.1), where: $H z_{\text {raw }}, V_{\text {raw }}$ - raw readings from encoders, $\left(l_{\text {comp }}\right)$ are readings along the compensator axis, $\left(t_{\text {comp }}\right)$ of the axis perpendicular to it, $A T R_{H z}$, $A T R_{V}$ - ATR system adjustment result

$$
\begin{gathered}
H z=H z_{\text {raw }}+A T R_{H z}+t_{\text {comp }} c t g V \\
V=V_{\text {raw }}+A T R_{V}+l_{\text {comp }}
\end{gathered}
$$

Due to the component of the horizontal angle correction, taking into account the vertical angle, the delay in determining the value of the horizontal angle relative to the distance will be greater than for the vertical angle. Assuming that the recording of individual quantities is carried out in the following order: distance, vertical angle, horizontal angle, and defining the $\mathrm{Y}$ axis parallel to the rectilinear motion path, deviations from the path in the horizontal $(\mathrm{mx})$ and vertical $(\mathrm{mz})$ planes can be determined. Their graphs will have a similar shape, with differing deviations $\mathrm{mx}$ and $\mathrm{mz}$, due to the greater delay in recording horizontal angles compared to vertical angles (Fig.2).
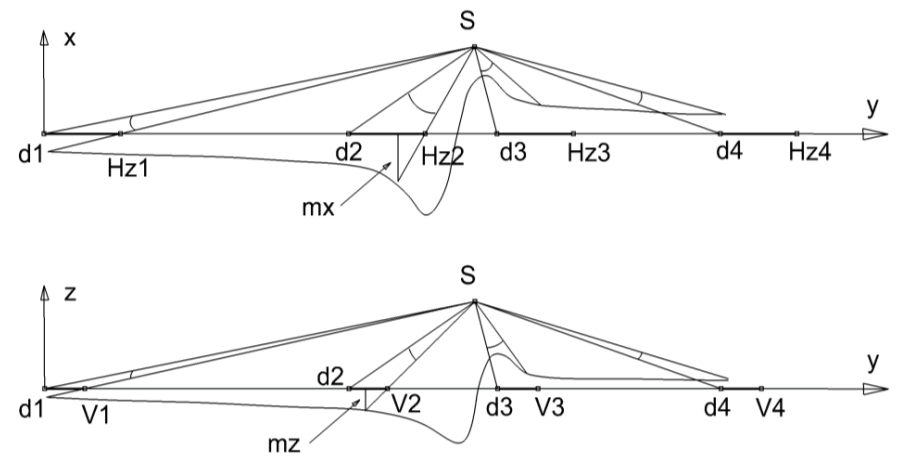

Fig. 2. Influence of time delays in recording angles relative to distances on accuracy of determining position of a moving prism in horizontal $(\mathrm{mx})$ and vertical $(\mathrm{mz})$ planes.

The values of deviations will depend both on the delays of the measurement systems in the robotized total station as well as on the velocity of the prism motion. The main question remains whether the values of deviations have a significant impact on the accuracy of the recorded position of the prism. 
The leading companies have developed at least four generations of RTS since the early 1990s. The analysis of progress in the field of kinematic measurements was presented in [22]. Several of the first tests of a tracking total station were presented in [7]. In a series of subsequent research papers, various authors pointed to the influence of non-simultaneous measurements of distances and angles on the accuracy of kinematic survey results. The tests were most frequently performed on a circular base or rectilinear test section $[19,20,21,13,17,14]$. Some of the tests were performed based on complex test devices. In [3], the test procedure was based on an electrodynamic shaker, which was designed to study the dynamic response characteristics of structures in the frequency range of $0 \div$ $200 \mathrm{~Hz}$. In [17], the prism placed on the robot arm moved at different speeds: along the straight line, along the shape of the letter $U$ and along the shape of the figure eight. During the tests, the total station was set both along the trajectory of the prism motion and transversely to it.

Already in the research paper [6], attention was paid to the synchronization of the instrument subsystems in kinematic surveys. The subsystem tests constituted the basis for determining calibration adjustments, from which calibration functions could be formulated. The study listed the most important subsystems requiring synchronous operation, and these included: EDM (electronic distance measurement), compensator, ATR (automatic target recognition) and Lock-Module. The Authors also tried to systematize the testing procedures of tracking total stations. Mutual interaction of the RTS (robotic total stations) subsystems was also described in [8]. In [20], formulas for adjustments of each coordinate and for the measurement time delay were derived, assuming a constant velocity of the target. This condition, however, rarely occurs in practical applications. The research study [21] tested four different tracking total stations, for the compensator which was on and off. For the TCA2003 instrument, turning the compensator on had little influence on the value of the delay, and for the TCRA 1101 it extended its time twice.

The temperature of operation has a significant influence on the functioning of electronic circuits, which in the case of complex measurement systems affects their synchronization. In [4], the Authors proposed a method of RTS synchronization with respect to the influence of temperature on the frequency drift of instrument internal clocks. They defined the speed of the drift at different temperatures in experiments performed in the climatic chamber, and they derived a calibration function based on these data.

In total stations with large time delays, measurement errors can reach decimeter values [19, 20, 13]. Errors of several dozen centimeters also occur [21], which can additionally be conditioned by a significant velocity of the prism motion. 
In more modern designs, as the sampling frequency increases, better accuracy can be expected. In [14], the Authors stated that modern total stations in the standard configuration perform measurements with variable frequency ranging from 7 to $10 \mathrm{~Hz}$, although it is possible to reach even more than $20 \mathrm{~Hz}$. The Authors also pointed out that the use of GeoCOM commands with appropriate parameters and the use of high speed USB or RS232 data transmission are particularly important. Modern ATR systems are able to automatically take variable measurement conditions into account, and they also have optimized algorithms for measuring dynamically moving objects [5]. For stable measurements of the mobile target, the control loop algorithms with better time synchronization are used, making it possible to change the direction of the prism motion faster, without losing its tracking. In addition, WFD (the Wave Form Digitizer) technology has been used in modern tracking instruments, which significantly affects the speed, accuracy and range of electro-optical distance measurements to mobile targets [15]. WFD is a type of distance measurement system that uses time of wave flight, but combines the advantages of the phase shift method and time of wave flight into one system.

According to the authors of the work [17], the accuracy obtained for a modern RTS Trimble SPS930 (frequency of up to $20 \mathrm{~Hz}$ ) was within the range 2-13 millimeters, which made it a significantly better result than in the case of older designs. However, the results obtained for the total station of a similar class: Leica MS50, carried out for the purpose of positioning UAV [18], demonstrated the existence of time delays for which the errors reached the values of up to $75 \mathrm{~mm}$.

It should be noted that the accuracy of the results of precise kinematic surveys is also affected by target signaling. In kinematic surveys, it is often impossible to properly orient the prism towards the total station due to its movement. Therefore, special $360^{\circ}$ prisms were designed. For this reason, the target, its orientation and the significance of the anti-reflective coating of the prisms became an important issue. Several works demonstrate the results of comparative analyzes of measurements performed to the $360^{\circ}$ prism and to a circular prism $[16,2]$. The influence of the development of $360^{\circ}$ prism designs (GRZ11 vs. GRZ4) and work modes (active vs. passive in Trimble MultiTrack $1000)$ on the quality of results [10] were also analyzed.

Detailed studies of the accuracy of the Leica TCRA 1102+ robotic total station, constituting the basis for current tests, were carried out in [13]. They were based on a measuring base that ensured the characteristics of errors illustrated in Figure 2. At the velocity of the prism comparable to that of a pedestrian, horizontal deviations reached the values of up to a dozen or so centimeters, while vertical ones were approximately twice smaller. The distribution of the deviations was consistent with Figure 2, indicating the recording in the following order: distance, vertical angle, horizontal 
angle. The data were recorded using the original software of the total station, and the target storage medium was a flash memory card. Similar tests, carried out using additional software, recording data on an external computer (transmission through the RS-232 serial port), allowed for several times reduction in the values of the errors, to a level of approximately $20-30 \mathrm{~mm}$. This suggests a significant dependence of the values of deviations not only on the delays of measurement systems, but also on the efficiency of computing electronics contained in total stations. Deviations at the level of single centimeters are already acceptable e.g. for topographic surveys (DTM), but for determining elements of technical infrastructure their values are still too high. The TCRA 1102+ total station represents the level of technology advancement from about the year 2000, and since then, a significant progress has been made in the field of computational electronics and instrument software. Most importantly, scanning total stations which have a much higher speed of measurement systems have appeared on the market (e.g. Leica Nova MS50 - $1000 \mathrm{pts} / \mathrm{sec}$ [12], and even up to $26600 \mathrm{pts} / \mathrm{sec}$ by RTS Trimble SX10 [9] in relation to the measurement in a tracking mode of TCRA $1102+$ typically $<0.15 \mathrm{~s}$, which is about $6-7 \mathrm{pts} / \mathrm{s}$ in good conditions [11]. Short observation time not only positively affects the scanning speed, but also reduces angle and distance recording delays, and thus, also the deviations occurring during the measurement of the mobile prism. The Leica Nova MS50 total station is an example of such a design. According to [12], the instrument measures angles $(\mathrm{Hz}, \mathrm{V})$, including, in automatic tracking mode, with standard deviation of 1 "(according to ISO 17123-3) and distances with standard deviation of $1 \mathrm{~mm}+1.5 \mathrm{~mm} / \mathrm{km}$ (according to ISO 17123 -4). The maximum frequency of measurements is $10 \mathrm{~Hz}$. Other technical parameters were not significant when measuring in laboratory conditions.

The objective of this research paper is to carry out tests, analyze the results and assess the possibilities of using robotic total stations with a high sampling frequency in measurements of moving prisms representing mobile objects. On the example of the Leica Nova MS50 total station, the influence of time delays in data recording on the accuracy of determining the position of the measured prism for current technical solutions used in robotic total stations was analyzed. It was particularly important to check whether the accuracy of measurements at the level of single millimeters is possible using modern RTS constructions.

\section{TEST PROCEDURE}

The research plan results directly from the error characteristics illustrated in Figures 1 and 2. In the metrological laboratory of the AGH Krakow University of Technology, a rectilinear prism motion 
path of a length of approximately $11 \mathrm{~m}$ was prepared. The $\mathrm{Y}$ axis was assumed along this path. Transverse deviations in the horizontal plane from this motion path result from horizontal angular delays relative to the distance ( $\mathrm{mx}$ errors), and vertical deviations from the vertical angular delays ( $\mathrm{mz}$ errors). The test track for measurements was a comparative base of electronic rangefinders, whose deviations from the straight line were cataloged on the basis of measurements made with the TC2002 precision instrument. It has the manufacturer's certificate for standard deviations of measured values: distances up to $200 \mathrm{~m}$ with standard deviation $0.2 \mathrm{~mm}+1.0 \mathrm{~mm} / \mathrm{km}$ (according to ISO 17123-4), angles with standard deviation 0.5 "(according to ISO 17123-3). The precision prism GPH1P was used in the measurements, and the instrument was positioned on the extension of the axis of the comparative base track. The determined deviations did not exceed $0.4 \mathrm{~mm}$. The track shape was then described using an interpolative spline function, taking into account its local unevenness, giving the track model. Deviations resulting from the analyzed time delays from such a defined track, were determined as the difference of the ordinates of the point: designated and model, for the same abscissa value. The trolley equipped with stepper motor moved along this track at a constant speed. The higher the velocity, the longer the distance covered by the prism between the recording of the distance and angle, and therefore the value of the deviation from the trajectory was higher. The tests were carried out for the speed of $1 \mathrm{~m} / \mathrm{s}$ (average pedestrian's speed) and $3 \mathrm{~m} / \mathrm{s}$. Based on the previously conducted tests, as well as on the analysis of the test results of other authors, two basic cases could be distinguished for which maximum and minimum deviations are recorded: when the prism moves in the transverse and longitudinal directions, relative to the total station measuring point. Drawings prepared in an analogous way as in the case of Fig. 1b or Fig. 2, make it possible to compare the deviations for the rectilinear and curvilinear motion paths (Fig. 3). For a prism moving transversely to the measuring point along the curvilinear paths, reaching the maximum deviation values, together with the change of their sign when passing the measuring point, is noticeable. These are the same characteristics as for a rectilinear path, with similar deviations.

Therefore, it is sufficient to carry out tests on rectilinear bases, orienting the instrument positions accordingly. The station located near the middle of the span of the measured base (defined briefly as middle or transversal), allows to determine the full characteristics of errors and to capture their maximum values. The station located at the end of the prism motion path (defined briefly as end) will display the results for a better setting of the RTS station, which allows to avoid the maximum values of deviations connected with the change of their sign (Fig.4). 


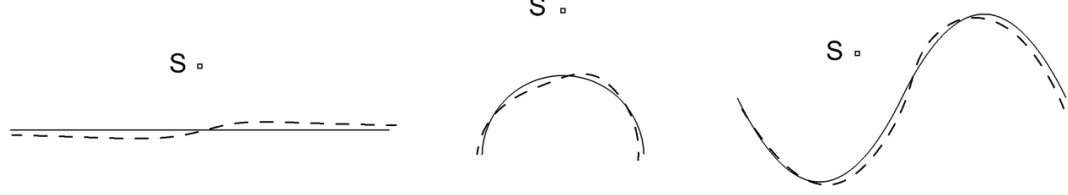

Fig. 3. Comparison of deviations for rectilinear and curvilinear prism motion paths. The real path is marked with a continuous line, the dotted line illustrates trajectory resulting from time delays in recording angles relative to lengths distances. S - the position of the instrument.

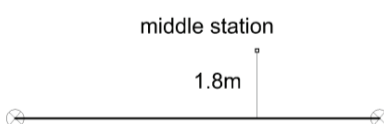

prism track $=9.2 \mathrm{~m}$

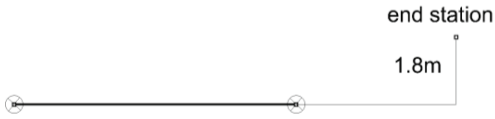

distance of the station from the end of the measuring line $=4.1 \mathrm{~m}$

Fig.4. Location of measuring stations relative to prism motion path.

During the tests, Leica GRZ4 $360^{\circ}$ was used. It is not a precise prism, but its use was necessary to carry out tests from the middle station, which allowed for determining the full characteristics of deviations. In addition, such prisms are widely used in measurements. The classical circular prism Leica GPR1 did not offer a range of sight lines which would be wide enough. Before the commencement of the tests, the accuracy characteristics of these prisms and precision prisms were prepared. The tests were performed on a fragment of the test base, which made it possible to carry out measurements for a classical prism.

All measurements were carried out in three series, demonstrated on the graphs (three independent passes). The total station performed measurements in the maximum measurement frequency mode of $10 \mathrm{~Hz}$. The initial and final fragments of the characteristics were removed for all the performed tests due to the slightly lower stability of the trolley during acceleration and braking. The speed was determined by means of appropriate gears, and it was measured on the basis of time of passing the trolley through the equidistant apertures set. On the graphs for the tests from the middle station, the position of the station along the prism track was marked with a vertical line. The effective length of the measuring path for the middle station was $9.2 \mathrm{~m}$, and for the end station it was $7.2 \mathrm{~m}$. The shorter length of the track for the end position resulted from the geometrical conditions in the comparator room. Setting the end position behind the measurement line required shortening the test track. 


\section{ANALYSIS OF RESULTS}

First, the characteristics of the circular prism GPR1 and GRZ4 $360^{\circ}$ were compared (Figs. 5 and 6). There were no significant differences identified for horizontal deviations (mx), which slightly exceeded the value of $1 \mathrm{~mm}$ for the $360^{\circ}$ prism in one point only. The essential differences occurred locally for vertical deviations (mz). Generally, the deviations for both prisms remained at a similar level and were smaller than the deviations $(\mathrm{mx})$. Locally, however, deviations of up to a maximum of $6 \mathrm{~mm}$ occurred for the $360^{\circ}$ prism. They were most probably associated with the observations made to the edges separating the neighboring surfaces of the prism. Similar disturbances can therefore be expected during further tests carried out using the $360^{\circ}$ prism.
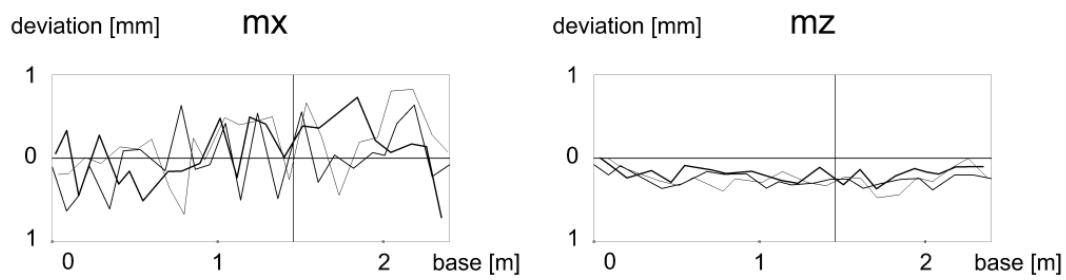

Fig. 5. Characteristics of deviations $\mathrm{mx}$ and $\mathrm{mz}$ for GPR1 circular prism.
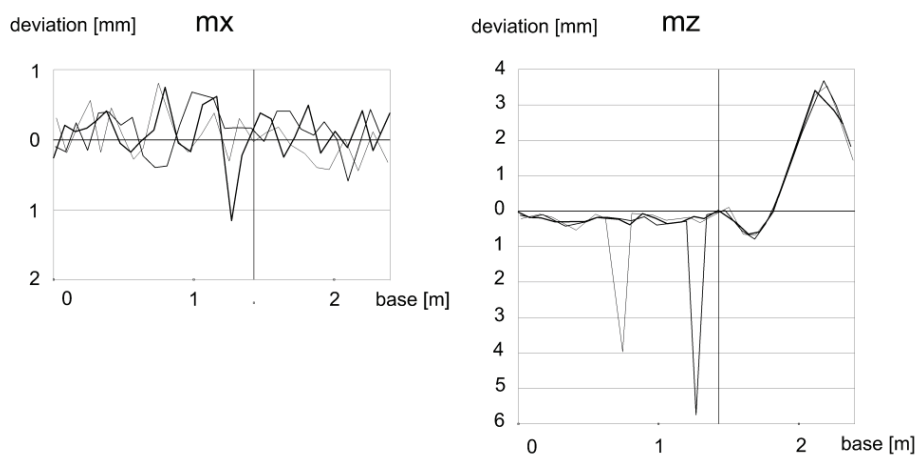

Fig. 6. Characteristics of deviations $\mathrm{mx}$ and $\mathrm{mz}$ for GRZ4 $360^{\circ}$ prism.

The results of the tests determining the values of the deviations $(\mathrm{mx})$ and $(\mathrm{mz})$ from the rectilinear motion path, depending on the position of the observation station and the prism velocity, are 
contained in the graphs (Fig. $7 \div 10$ ) and Table 1 . The lines with different thicknesses indicate the results of subsequent measurement series.
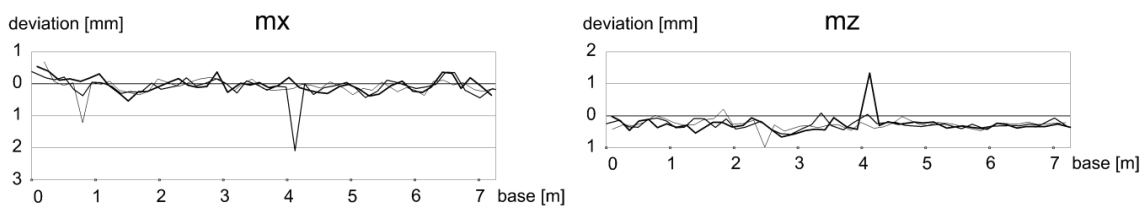

Fig. 7. Station behind the end of the measuring line, prism velocity $1 \mathrm{~m} / \mathrm{s}$.
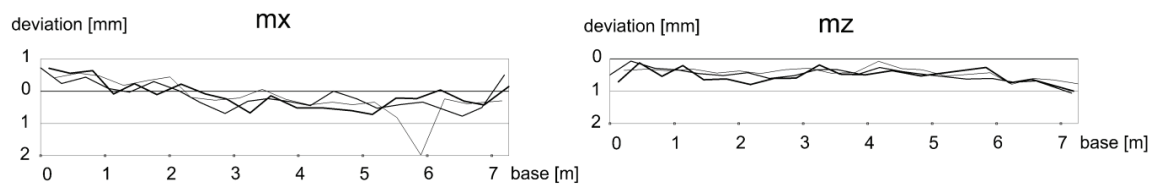

Fig. 8. Station behind the end of the measuring line, prism velocity $3 \mathrm{~m} / \mathrm{s}$.
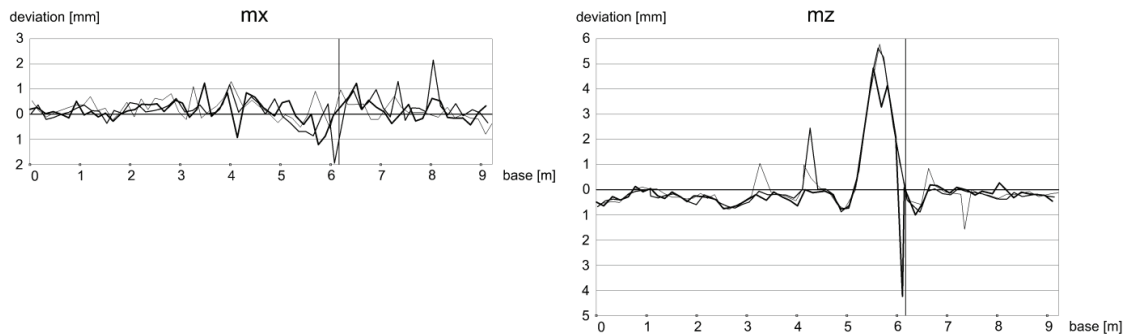

Fig. 9. Station in the middle of the measuring line (transversal), prism velocity $1 \mathrm{~m} / \mathrm{s}$.
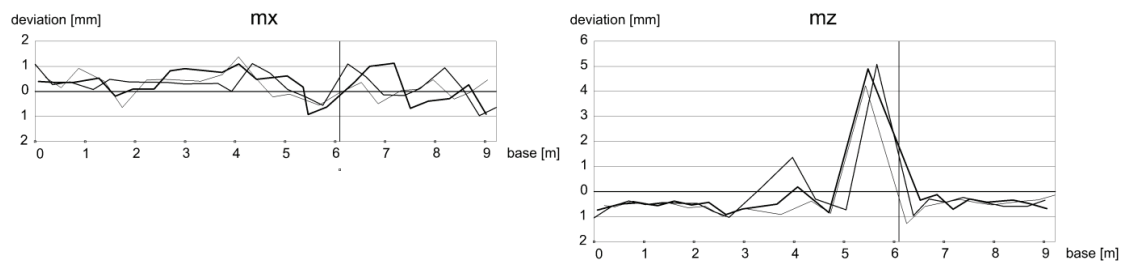

Fig. 10. Station in the middle of the measuring line (transversal), prism velocity $3 \mathrm{~m} / \mathrm{s}$. 
When referring the results to the characteristics of the $360^{\circ}$ prism, the occurrence of analogous vertical coordinate errors $(\mathrm{mz})$ should be noted. They occurred for the measurements at the middle station, near to the point where the prism was passing the station, when there is a change in the plane of the prism that the total station is aimed at. The values of the deviations were also similar (up to $6 \mathrm{~mm}$ ). Such deviations should therefore be treated as deviations resulting from the construction of the prism, and not from the time delays of the subsystems of the instrument. The measurements at the end station did not exhibit errors $(\mathrm{mz})$ related to the change in aiming between the prism planes, because the moving prism remained approximately in the same position in relation to the sight line.

Table 1. Values of deviations mx and my depending on position of instrument position and prism velocity.

\begin{tabular}{|c|c|c|c|c|c|c|}
\hline \multirow[t]{2}{*}{ station } & \multirow[t]{2}{*}{ speed } & \multirow[t]{2}{*}{ series } & \multicolumn{2}{|c|}{$\mathrm{mx}[\mathrm{mm}]$} & \multicolumn{2}{|c|}{$\mathrm{mz}[\mathrm{mm}]$} \\
\hline & & & average & maximum & average & maximum \\
\hline \multirow[t]{8}{*}{ end } & \multirow[t]{4}{*}{$1[\mathrm{~m} / \mathrm{s}]$} & 1 & 0.2 & 1.3 & 0.3 & 0.8 \\
\hline & & 2 & 0.2 & 0.6 & 0.3 & 1.0 \\
\hline & & 3 & 0.2 & 2.1 & 0.3 & 1.3 \\
\hline & & average & 0.2 & 2.1 & 0.3 & 1.3 \\
\hline & \multirow[t]{4}{*}{$3[\mathrm{~m} / \mathrm{s}]$} & 1 & 0.3 & 0.6 & 0.4 & 1.0 \\
\hline & & 2 & 0.3 & 0.8 & 0.5 & 0.8 \\
\hline & & 3 & 0.5 & 2.0 & 0.5 & 1.1 \\
\hline & & average & 0.4 & 2.0 & 0.5 & 1.1 \\
\hline \multirow[t]{8}{*}{ middle } & \multirow[t]{4}{*}{$1[\mathrm{~m} / \mathrm{s}]$} & 1 & 0.4 & 2.2 & 0.6 & 5.7 \\
\hline & & 2 & 0.3 & 2.0 & 0.7 & 5.8 \\
\hline & & 3 & 0.3 & 1.4 & 0.6 & 5.1 \\
\hline & & average & 0.4 & 2.2 & 0.6 & 5.8 \\
\hline & \multirow[t]{4}{*}{$3[\mathrm{~m} / \mathrm{s}]$} & 1 & 0.4 & 1.2 & 0.8 & 5.1 \\
\hline & & 2 & 0.5 & 1.2 & 0.9 & 5.0 \\
\hline & & 3 & 0.5 & 1.4 & 0.8 & 4.3 \\
\hline & & average & 0.5 & 1.4 & 0.8 & 5.1 \\
\hline
\end{tabular}

The high frequency of observations performed by the Leica MS50 tachymeter caused that the deviations resulting from delays in recording angles in relation to the distances are very small. Thus, they are quite difficult to detect on charts and it is easier to assess a certain systematics by analyzing tabular data. The most important observation indicates that the results confirm the possibility of obtaining accuracy at the level of a few millimeters, which is expected in the 
implementation of the tasks mentioned in the introduction. The average values of deviations are smaller than it results from the technical specification of the tested instrument. Nevertheless, the regularities related to the location of the measuring station relative to the track or the speed of the prism movement are noticeable and repeatable.

Taking into account the characteristics of the $360^{\circ}$ prism and their influence on the deviations (mz), it can be noticed that the deviations generally did not exceed $0.5 \mathrm{~mm}$, and the maximum ones sporadically exceeded $2 \mathrm{~mm}$.

The effect of different velocities of the prism $(1 \mathrm{~m} / \mathrm{s}$ and $3 \mathrm{~m} / \mathrm{s})$ on the measurement results can be seen more clearly in tabular formulas. The average values of deviations $(\mathrm{mx})$ and $(\mathrm{mz})$ at the end station increase respectively: from 0.2 to $0.4 \mathrm{~mm}$ and from 0.3 to $0.5 \mathrm{~mm}$, and when measuring on middle station: from 0.4 to $0.5 \mathrm{~mm}(\mathrm{mx})$ and from 0.6 to $0.8 \mathrm{~mm}(\mathrm{mz})$. The average values of deviations $(\mathrm{mx})$ are slightly smaller for all cases than the deviation (mz).

High sampling frequency also eliminates the influence of the position of the station on measurement errors. At the middle station, with random measurement noise, it is difficult to clearly observe characteristic deviations associated with delays in recording angles relative to distances. One may try to point them in the vicinity of the station (marked with a vertical line in figure 9 and 10), where deviations change the sign, although this is not the only place where this sign is changed. In general, when analyzing tabular deviation values, the influence of the position of the station is noticeable. At the middle stations, the increase in mean deviations was observed if compared to the end stations: at the velocity of $1 \mathrm{~m} / \mathrm{s}(\mathrm{mx})$ from 0.2 to $0.4 \mathrm{~mm}$ and $(\mathrm{mz})$ from 0.3 to $0.6 \mathrm{~mm}$, and at the velocity of $3 \mathrm{~m} / \mathrm{s}$ : (mx) from 0.4 to $0.5 \mathrm{~mm}$ and $(\mathrm{mz})$ from 0.5 to $0.8 \mathrm{~mm}$.

It should be noted that at lower velocities of the prism, larger, single, maximum deviations were generally observed. It may have been related to a small wobble of the trolley, for which it was more difficult to overcome potential minor unevenness of the track at lower speeds.

The comparison of the small, few-millimeter deviations and the deviations for the same instrument, which were noted in the paper [18], was very interesting. They were several dozen times larger, reaching values of up to $75 \mathrm{~mm}$, which the Authors of this research paper assessed as adequate for the instruments of the older generation. In addition, these tests were performed at the prism motion speed which was lower than the one in the current tests $(0.1 \div 0.2 \mathrm{~m} / \mathrm{s}$ compared to $1 \div 3 \mathrm{~m} / \mathrm{s})$, and the higher speed affects the increase in the average values of deviations. Due to the fact that no such considerable deviations were observed during the current tests, a question has arisen regarding the correctness of the measurement system configuration in the mentioned studies. However, the results 
of the current tests were better than those obtained in the study [17] for the total station with a similar specification (Trimble SPS930).

\section{SUMMARY AND CONCLUSIONS}

The performed tests provided the results that allowed for the assessment of the applicability of robotized total station of high sampling frequency, to various tasks related to measurements of mobile targets. Time delays in the recording of the angles relative to the distances, in combination with the position of the total station relative to the mobile target and its velocity, are the key factors affecting the values of measurement deviations. They are easy to observe in the case of lowfrequency total stations, e.g. Leica TCRA $1102+$ [13]. The tests currently performed for the Leica MS50 total station have demonstrated, that the time delays in the recording of the angles relative to the distances are so small, that they largely eliminate the influence of the localization of measurement stations and the velocity of the prism (at speeds up to several $\mathrm{m} / \mathrm{s}$ ). These factors are still noticeable, but in terms of average values, they did not result in differences greater than a tenth of a millimeter, which was difficult to observe in the graphs. In general, the mean deviations did not exceed $0.5 \mathrm{~mm}$. Maximum deviations incidentally exceeded $2 \mathrm{~mm}$, usually reaching approximately $1 \mathrm{~mm}$. This proves the possibility of using modern robotic total stations with a high sampling frequency for many applications related to the use of mobile prisms. The factor which requires future research studies are tests at much higher speeds, appropriate for the cases in which the prism will be located on standard, mechanically driven vehicles.

Acknowledgement: The article was prepared as part of the AGH statutory research No. 11.11.150.005. 


\section{REFERENCES}

1. M. Ehrhart, W. Lienhart, "Object tracking with robotic total stations: Current technologies and improvements based on image data", Journal of Applied Geodesy 11(3): 131-142, 2017.

2. C. Favre C, M. Hennes M. "Zum Einfluss der geometrischen Ausrichtung von $360^{\circ}$-Reflektoren bei Messungen mit automatischer Zielerfassung", Mensuration, photogrammetrie, genie rural 98(2): 72-78, 2000.

3. V. Gikas, S. Daskalakis, "Full Scale Validation of Tracking Total Stations Using a Long Stroke Electrodynamic Shaker" Shaping the Change. XXIII International FIG Congress, 2006.

4. Z. Gojcic, S. Kalenjuk, W. Lienhart, "Synchronization routine for real-time synchronization of robotic total stations", INGENEO 2017: Proceedings of the 7th International Conference on Engineering Surveying: 83-91, 2017.

5. D. Grimm, U. Hornung, "Leica ATRplus - Leistungssteigerung der automatischen Messung und Verfolgung von Prismen", AVN - allgemeine vermessungs-nachrichten 8-9: 269-276, 2015.

6. M. Hennes, B. Krickel, "Zur Entwicklung von Untersuchungsverfahren zur Bestimmung der Leistungsfähigkeit von Robot-Tachymetern" Flächenmanagement und Bodenordnung (FuB): 26-33, 2000.

7. M. Hennes, "Leistungsmerkmale des One-Man-Systems Geodimeter System 4000", VR 4(5): 287-295, 1992.

8. H. Kirschner, W. Stempfhuber, "The kinematic potential of modern tracking total stations - a state of the art report on the Leica TPS1200+", Proceedings of the 1st International Conference on Machine Control \& Guidance 24(26): 51-60, 2008.

9. E. Lachat, T. Landes, P. Grussenmeyer, "First experiences with the Trimble SX10 Scanning Total Station for building facade survey", The International Archives of Photogrammetry, Remote Sensing and Spatial Information Sciences 42: 405-412, 2017.

10. S. Lackner, W. Lienhart, "Impact of Prism Type and Prism Orientation on the Accuracy of Automated Total Station Measurements", Proc. 3rd Joint International Symposium on Deformation Monitoring, 2016.

11. Leica Geosystems AG, "Leica TPS1100 series", www.leica-geosystems.com, 1999.

12. Leica Geosystems AG, "White paper Leica Nova MS50", www.leica-geosystems.com, 2013.

13. G. Lenda, "Determining the measurement accuracy for moving georadar using a robotized tacheometer with optional automatic target recognition", Polish Academy of Sciences. Geodesy 43: 99-112, 2007.

14. W. Lienhart, M. Ehrhart, M. Grick, "High Frequent Total Station Measurements for the Monitoring of Bridge Vibrations", Journal of Applied Geodesy 11(1): 1-8, 2017.

15. H. Maar, H-M. Zogg, "WFD - Wave Form Digitizer Technology. Technical report", Leica Geosystems AG, 2014.

16. J. Mao, D. Nindl, "Surveying Reflectors - White Paper. Characteristics and Influences", Leica Geosystems AG, 2009.

17. D. S. Paraforos, M. Reutemann, G. Sharipov, R. Werner, H. W. Griepentrog, "Total station data assessment using an industrial robotic arm for dynamic 3D in-field positioning with sub-centimetre accuracy", Computers and Electronics in Agriculture 136: 166-175, 2017.

18. C. Roberts, P. Boorer, "Kinematic positioning using a robotic total station as applied to small-scale UAVs", Journal of Spatial Science 61(1): 29-45, 2016.

19. R. Staiger, "Zur Uberprufung moderner Vermessungsinstrumente (Verification modern surveying instruments)", Allgemeine Vermessungs-Nachrichten 105(11/12): 365-372, 1998.

20. W. Stempfhuber, K. Schnadelbach, W. Maurer, "Genaue Positioniering von bewegten Objekten mit zielverfolgenden Tachymetern", Ingenieurvermessung 2000. XIII International Course on Engineering Surveying: 144-154, 2000.

21. W. Stempfhuber, "The Integration of Kinematic Measuring Sensors For Precision Farming System Calibration", The 3rd International Symposium on Mobile Mapping Technology. FIG Symposium Cairo, 2001.

22. W. Stempfhuber, "Verification of the Trimble Universal Total Station (UTS) performance for kinematic applications", Proceedings of Optical 3-D measurement techniques: applications in GIS, mobile mapping, manufacturing, quality control, robotics, navigation, cultural heritage, natural and manmade hazards monitoring, medical imaging, VR generation and animation: 211-221, 2009.

23. Trimble Inc., "Trimble SX10 Scanning Total Station Information and Datasheet", https://geospatial.trimble.com, 2018.

\section{LIST OF FIGURES AND TABLES:}


Fig. 1. Influence of time delays on accuracy of determining position of a mobile prism moving along a straight line. 1a - delays in recording distances in relation to angles, $1 \mathrm{~b}$ - delays in recording angles in relation to distances. The bold line represents distance traveled by prism between recording time of distances and angles, S - station.

Rys.1. Wpływ opóźnień czasowych na dokładność wyznaczenia pozycji ruchomego pryzmatu, poruszającego się wzdłuż prostoliniowego toru. 1a - opóźnienia rejestracji długości względem kątów, 1b opóźnienia rejestracji kątów względem długości. Pogrubioną linią zaznaczono drogę, jaką przebywa pryzmat pomiędzy czasem rejestracji długości i kątów.

Fig. 2. Influence of time delays in recording angles relative to distances on accuracy of determining position of a moving prism in horizontal (mx) and vertical (mz) planes.

Rys.2. Wpływ opóźnień czasowych rejestracji kątów względem długości na dokładność wyznaczenia pozycji ruchomego pryzmatu w płaszczyźnie poziomej (mx) i pionowej (mz).

Fig. 3. Comparison of deviations for rectilinear and curvilinear prism motion paths. The real path is marked with a continuous line, the dotted line illustrates trajectory resulting from time delays in recording angles relative to lengths distances. S - the position of the instrument.

Rys.3. Porównanie odchyłek dla prostoliniowego i krzywoliniowych torów ruchu pryzmatu. Linią ciągłą zaznaczono rzeczywisty tor ruchu, linia przerywana to tor ruchu wyznaczony na skutek opóźnień czasowych rejestracji kątów względem długości. S - stanowisko instrumentu.

Fig.4. Location of measuring stations relative to prism motion path.

Rys.4. Usytuowanie stanowisk pomiarowych względem toru ruchu pryzmatów.

Fig. 5. Characteristics of deviations $\mathrm{mx}$ and $\mathrm{mz}$ for GPR 1 circular prism.

Rys. 5. Charakterystyki odchyłek mx i mz dla pryzmatu okrągłego GPR1.

Fig. 6. Characteristics of deviations $\mathrm{mx}$ and $\mathrm{mz}$ for GRZ4 $360^{\circ}$ prism.

Rys. 6. Charakterystyki odchyłek mx i mz dla pryzmatu GRZ4 $360^{\circ}$.

Fig. 7. Station behind the end of the measuring line, prism velocity $1 \mathrm{~m} / \mathrm{s}$.

Rys. 7. Stanowisko za końcem linii pomiarowej, prędkość pryzmatu $1 \mathrm{~m} / \mathrm{s}$.

Fig. 8. Station behind the end of the measuring line, prism velocity $3 \mathrm{~m} / \mathrm{s}$.

Rys. 8. Stanowisko za końcem linii pomiarowej, prędkość pryzmatu $3 \mathrm{~m} / \mathrm{s}$.

Fig. 9. Station in the middle of the measuring line (transversal), prism velocity $1 \mathrm{~m} / \mathrm{s}$.

Rys. 9. Stanowisko w środku linii pomiarowej (poprzeczne), prędkość pryzmatu 1m/s.

Fig. 10. Station in the middle of the measuring line (transversal), prism velocity $3 \mathrm{~m} / \mathrm{s}$. Rys. 10. Stanowisko w środku linii pomiarowej (poprzeczne), prędkość pryzmatu 3m/s.

Tab. 1. Values of deviations $\mathrm{mx}$ and my depending on position of instrument position and prism velocity. Tab.1. Wartości odchyłek mx i my w zależności od położenia stanowiska instrumentu i prędkości ruchu pryzmatu. 


\section{WPLYW OPÓŹNIEŃ CZASOWYCH TACHIMETRÓW ZROBOTYZOWANYCH O DUŻEJ CZESTOTLIWOŚCI REJESTRACJI NA DOKLADNOŚĆ POMIARÓW DO RUCHOMYCH PRYZMATÓW}

Słowa kluczowe: pomiar w ruchu, pomiar położenia, pomiary kinematyczne, techniki pomiarowe, tachimetry zrobotyzowane

\section{STRESZCZENIE:}

Tachimetry zrobotyzowane (RTS) stanowią grupę instrumentów geodezyjnych, które mogą być używane do pomiaru pryzmatów znajdujących się w ruchu. Mogą one znaleźć zastosowanie podczas oceny stanu technicznego infrastruktury inżynierskiej, np.: dla potrzeb regulacji torów kolejowych, pomiaru suwnic, sterowania maszyn budowlanych. Są także użyteczne w innych zastosowaniach: budowie numerycznego modelu terenu, wyznaczaniu pozycji georadaru czy echosondy. Urządzenia te spełniają wymagania dokładnościowe zgodnie ze specyfikacją techniczną producenta dla pomiarów celów statycznych, jednak mogą generować istotne błędy podczas pomiarów kinematycznych. Spowodowane jest to różną szybkością działania podsystemów pomiarowych tachimetru, co skutkuje wykonaniem obserwacji ustalających pozycję punktu w różnych miejscach przestrzeni. Konstrukcje tachimetrów sprzed kilkunastu lat mogą generować błędy o wartościach nawet kilkudziesięciu centymetrów. Nowsze konstrukcje, posiadające znacznie mniejsze opóźnienia podsystemów mechaniczno-elektronicznych, teoretycznie pozwalają istotnie zmniejszyć wartości błędów. W opracowaniu przeprowadzono kinematyczne testy współczesnego tachimetru zrobotyzowanego Leica MS50 pod kątem oceny wartości błędów pomiarowych, a tym samym możliwości użycia do wyżej wymienionych zastosowań.

Określanie pozycji ruchomego pryzmatu odbywa się w analogiczny sposób jak celów nieruchomych, poprzez pomiar odległości oraz kąta pionowego i poziomego. Te trzy wielkości, ze względów technicznych, nie mogą być jednak rejestrowane dokładnie w tym samym czasie. Dla pomiarów statycznych nie ma to znaczenia, ponieważ punkt pozostaje w spoczynku. Podczas pomiarów zrobotyzowanych, w trakcie ciągłego ruchu pryzmatu, wzajemne opóźnienia czasowe rejestracji długości i kątów mogą negatywnie wpływać na dokładność, ponieważ na pozycję punktu składają się obserwacje wykonane w różnych miejscach przestrzeni. Aby wyznaczyć wartości tak powstałych błędów, przeprowadzono badania na prostoliniowym torze w laboratorium metrologicznym AGH w Krakowie. Do analiz przyjęto, że oś toru, po którym poruszał się obserwowany pryzmat pokrywa się z osią Y prostokątnego układu współrzędnych. Poprzeczne odchyłki od tego toru w płaszczyźnie poziomej wynikają z opóźnień kątów poziomych względem długości (odchyłki mx), w pionowej, z opóźnień kątów pionowych (odchyłki mz). Tor testowy do pomiarów stanowiła baza komparacyjna dalmierzy tachimetrów elektronicznych, której odchyłki od linii prostej zostały skatalogowane na podstawie pomiarów wykonanych tachimetrem precyzyjnym TC2002. Kształt toru został następnie opisany za pomocą interpolacyjnej funkcji sklejanej, uwzględniającej jego lokalne nierówności, dając model toru. Odchyłki wynikające z analizowanych opóźnień czasowych od tak określonego toru, wyznaczono jako różnicę rzędnych punktu - wyznaczonej i modelowej dla tej samej wartości odciętych. Po torze tym poruszał się ze stałą prędkością wózek napędzany silnikiem krokowym. Badania przeprowadzono dla prędkości $1 \mathrm{~m} / \mathrm{s}$ (przeciętna prędkość piechura) i $3 \mathrm{~m} / \mathrm{s}$. Na podstawie uprzednio prowadzonych testów, jak i analizy wyników badań innych autorów, można wyróżnić dwa zasadnicze przypadki, dla których odnotowywane są maksymalne i minimalne wartości odchyłek: kiedy pryzmat porusza się na kierunku poprzecznym i wzdłużnym względem stanowiska tachimetru. Stanowisko zlokalizowane w okolicach środka rozpiętości mierzonego obiektu (środkowe) pozwala na określenie pełnej 
charakterystyki odchyłek i wychwycenie maksymalnych ich wartości. Stanowisko zlokalizowane za końcem toru ruchu pryzmatu zobrazuje wyniki dla lepszego ustawienia tachimetru, które pozwala na uniknięcie maksymalnych wartości odchyłek połączonych ze zmianą ich znaku. Testy laboratoryjne przeprowadzono $\mathrm{w}$ trzech seriach (trzy niezależne przejazdy). Tachimetr wykonywał pomiary w trybie maksymalnej częstotliwości pomiarowej, wynoszącej $10 \mathrm{~Hz}$.

Uzyskane w testach wyniki pozwoliły ocenić możliwości zastosowania tachimetrów zrobotyzowanych o dużej częstości rejestracji do różnorodnych zadań związanych z pomiarami ruchomych celów. Opóźnienie czasu rejestracji kątów względem długości, w połączeniu z pozycją stanowiska tachimetru względem przemieszczającego się celu oraz jego prędkością, są kluczowymi czynnikami wpływającymi na wartości odchyłek pomiarów. Są one łatwe do zaobserwowania w przypadku tachimetrów o małej częstości rejestracji, np. Leica TCRA 1102+. Testy przeprowadzone dla tachimetru Leica MS50 wykazały, że opóźnienia czasowe rejestracji kątów względem długości są tak nieznaczne, że w dużym stopniu eliminują wpływ rozmieszczenia stanowisk pomiarowych oraz prędkości pryzmatu (przy prędkościach do kilku m/s). Czynniki te są w dalszym ciągu zauważalne, jednak ich wpływ na wartości średnie w przejazdach nie przekraczał dziesiątych części milimetra, co było trudne do zauważenia na wykresach. Ogólnie odchyłki średnie były na poziomie nie większym niż $0.5 \mathrm{~mm}$. Odchyłki maksymalne incydentalnie przekraczały $2 \mathrm{~mm}$, zazwyczaj dochodząc do ok. $1 \mathrm{~mm}$. Uzyskane wyniki wskazują na możliwość użycia nowoczesnych tachimetrów zrobotyzowanych o dużej częstości rejestracji do wielu zastosowań związanych z pomiarami kinematycznymi do przemieszczających się obiektów z zamontowanym pryzmatem. 